\title{
EFEKTIVITAS PENGELOLAAN ALOKASI DANA DESA DALAM
}

PEMBANGUNAN FISIK DI DESA BATUJAJAR TIMUR KABUPATEN

BANDUNG BARAT

\author{
Dzenta Masitha1), Yamardi2), Toto Kushartono ${ }^{3)}$
}

\author{
1), 2), 3)Prodi Ilmu Pemerintahan, Fakultas Ilmu Sosial dan Ilmu Politik, \\ Universitas Jenderal Achmad Yani Cimahi - Bandung
}

\begin{abstract}
Abstrak
Masalah yang terjadi di Desa Batujajar Timur adanya ketidaksesuaian alokasi dana desa yang diterima sesuai dengan realisasi, adanya keterlambatan dalam pencairan alokasi dana desa, belum meratanya pembangunan fisik di Desa Batujajar Timur. Pengelolaan alokasi dana desa belum dapat dikatakan efektif, jika ditinjaun dari tepat, cepat, hemat, dan selamat. Penelitian ini menggunakan metode penelitian deskriptif dengan pendekatan Kualitatif. Data yang diperoleh melalui hasil studi kepustakaan, studi lapangan yang melalui tahap wawancara mendalam dan observasi, serta dokumentasi. Hasil penelitian menunjukan bahwa Pengelolaan Alokasi Dana Desa Dalam Pembangunan Fisik Di Desa Batujajar Timur Kecamatan Batujajar Kabupaten Bandung Barat, belum dapat dikatakan efektif, karena kurangnya partisipasi masyarakat dalam Musrenbangdes, alokasi dana desa yang diterima tidak sesuai dengan ketetapan pemerintah yang pada teorinya didapat pada bulan Januari dan dilaporkan pada bulan Desember, sarana dana prasarana yang belum menunjang, alokasi dana desa yang didapatkan tidak sesuai dengan realisasi.
\end{abstract}

Kata Kunci: Efektivitas, Pengelolaan, Alokasi Dana Desa, Pembangunan

\begin{abstract}
The problems that occur in Batujajar Timur Village are the mismatch of village fund allocations received according to the realization, the delay in disbursing village fund allocations, the uneven physical development in Batujajar Timur Village. The management of village fund allocations cannot be said to be effective, if it is reviewed correctly, quickly, economically, and safely. This study uses a descriptive research method with a qualitative approach. The data obtained through the results of library research, field studies through in-depth interviews and observations, and documentation. The results showed that the management of Village Fund Allocation in Physical Development in Batujajar Timur Village, Batujajar Subdistrict, West Bandung Regency, cannot be said to be effective, due to the lack of community participation in musrenbangdes, the village fund allocation received is not by government regulations which in theory were obtained in January. and it was reported in December, the facilities for infrastructure funds were not yet supported, the allocation of village funds obtained did not match the realization.
\end{abstract}

Keywords: Effectiveness, Management, Village Fund Allocation, Development 


\section{PENDAHULUAN}

Desa mempunyai Hak untuk mengatur wilayah dengan kewenangan yang diberikan oleh Pemerintah Pusat untuk menjalankan urusan pemerintahan serta membuat aturan untuk mengatur masyarakat desa setempat dengan tetap mengacu pada Undang-Undang yang berlaku. Seperti yang tertera didalam Undang Undang Nomor 23 tahun 2014 tentang Pemerintahan Daerah Pasal 371 ayat (1) dan (2) menyatakan: (1) Dalam Daerah Kabupaten/Kota dapat dibentuk Desa; (2) Desa sebagaimana dimaksud pada ayat (1) mempunyai kewenangan sesuai dengan ketentuan peraturan perundang-undangan mengenai Desa.

Otonomi Desa menjadi satu hal yang bulat dan asli, ialah Desa memiliki otoritas sendiri untuk menjalankan urusan pemerintahan dan membuat kebijakan (Peraturan Desa) dengan tetap mengacu pada perundang-undangan yang berlaku. Otonomi Desa diberikan karena Pemerintah Desa selaku pihak yang terjun langsung dan berinteraksi dengan masyarakat Desa, sehingga Pemerintah Desa lebih mengetahui kondisi dan keadaan masyarakat Desa.

Pemerintah Desa tidak dapat terlepas akan kebutuhan sumber dana untuk menjalankan pembangunan yang berkesinambung demi kemaslahatan masyarakat Desa secara merata. Salah satu faktor penentu dapat dikatakan berhasil atau tidaknya suatu pembangunan ditingkat Desa maupun skala nasional adalah terwujudnya penyelenggaraan Pemerintahan yang berdayaguna dan berhasilguna serta partisipatif (ikut serta) masyarakat mulai dari tahap perencanaan, pelaksanaan hinga tahap evaluasi, oleh karena itu perlu pemberian dukungan sumber dana yang memadai yang diberikan oleh Pemerintah Pusat melalui Pemerintah Daerah kepada Desa melalui sumber-sumber transfer seperti Alokasi Dana Desa, Dana Desa maupun sumber pendapatan lain dalam keuangan desaAnggarana Pendapatan dan Belanja Desa (APBDesa). Sumber dana yang dapat digunakan untuk melaksanakan fungsi pemerintah ditingkat desa dapat diterima melalui sumber dana transfer yakni Alokasi Dana Desa yang diberikan oleh Pemerintah Kabupaten kepada Desa melalui Dinas Pembangunan 
dan Pemberdayaan Masyarakat Desa dalam bentuk transfer yang diberikan kepada Pemerintah Desa diseluruh Kabupaten yang diterima oleh tiap Bendahara Desa di Kabupaten masing-masing. Sumber dana yang diberikan oleh Pemerintah Pusat maupun Pemerintah Daerah kepada Desa memiliki tujuan yakni agar Pemerintah Desa dapat menjalankan otonomi desa demi tercapainya pembangunan desa yang merata di seluruh Indonesia dan masyarakat desa sejahtera sesuai dengan Amanat Pembukaan Undang-Undang Dasar 1945.

Desa Batujajar Timur yang berada di Kecamatan Batujajar Kabupaten Bandung Barat, dengan jumlah penduduk Kecamatan Batujajar sebesar 90.188,085 jiwa yang tersebar di 7 (tujuh) Desa. Penduduk Desa Batujajar Timur memiliki jumlah penduduk sebesar 14.228 jiwa. Alokasi Dana Desa yang didapat oleh Pemerintah Desa Batujajar Timur dikelola secara mandiri oleh Perangkat Desa Batujajar Timur, Alokasi Dana Desa yang didapatkan Desa Batujajar Timur yang didapat melalui Dinas Pembangunan dan Pemberdayaan Masyarakat Desa Kabupaten Bandung Barat sebesar Rp. 673.375.500 yang dikelola dan dipergunakan sebesar 30\% (tigapuluh perseratus) untuk Penyelenggaraan Pemerintahan Desa Batujajar Timur. Alokasi Dana Desa dipergunakan 70\% (tujuhpuluh perseratus) untuk pemberdayaan dan pembangunan Desa Batujajar Timur. Dijelaskan dalam bentuk tabel dibawah ini:

Tabel 1

Penggunaan Alokasi Dana Desa Tahun Anggaran 2017 di Desa Batujajar Timur

\begin{tabular}{|c|c|c|c|}
\hline $\begin{array}{c}\text { REALISASI } \\
\text { ALOKASI } \\
\text { DANA DESA T.A } \\
2017 \\
\end{array}$ & $\begin{array}{c}\text { ALOKSAI } \\
\text { DANA DESA } \\
\text { T.A } 2017\end{array}$ & DIGUNAKAN & KETERANGAN \\
\hline \multirow[t]{2}{*}{ Rp. 673.375.500 } & \multirow[t]{2}{*}{ Rp.658.905.500 } & $\begin{array}{l}30 \% \text { untuk } \\
\text { Penyelenggaraan } \\
\text { Pemerintahan }\end{array}$ & $\begin{array}{l}\text { Insentif RT/RW } \\
\text { yang berada di } \\
\text { Desa Batujajar } \\
\text { Timur, upah } \\
\text { Linmas juga } \\
\text { penetapan upah } \\
\text { tetap Kepala } \\
\text { Desa beserta } \\
\text { Perangkat Desa } \\
\text { dan Operasional } \\
\text { BPD Batujajar } \\
\text { Timur }\end{array}$ \\
\hline & & & Pemberdayaan \\
\hline
\end{tabular}




\begin{tabular}{l|l} 
70\% untuk & Melalui \\
Pemberdayaan & BUMDesa, \\
Masyarakat dan & serta \\
Pembangunan & Pemeliharaan \\
Desa & Infrastruktur \\
& Desa Batujajar \\
& Timur
\end{tabular}

\section{Sumber: Sekretaris Desa Batujajar Timur, Diolah oleh Peneliti 2018}

Alokasi Dana Desa Batujajar Timur dikelola oleh Perangkat Desa yang diawasi oleh BPD Batujajar Timur. Alokasi dana desa dalam pembangunan memiliki tujuan untuk mencapai kesejahteraan masyarakat Desa Batujajar Timur secara merata. Pengelolaan Alokasi Dana Desa Desa Batujajar Timur digunakan sebesar 30\% untuk penyelenggaraan pemerintahan sebesar Rp. 197.671.650 digunakan untuk penetepan upah tetap Kepala Desa beserta Perangkat Desa selama satu tahun, operasional BPD Desa Batujajar Timur. Sedang pengelolaan Alokasi Dana Desa Desa Batujajar Timur sebesar 70\% dipergunakan untuk pemberdayaan, pembangunan desa dan ekonomi Desa Batujajar Timur sebesar Rp. 488.233.850 untuk pembangunan dan pemeliharaan pembangunan desa serta pemberdayaan masyarakat Desa seperti PKK, dan juga modal untuk usaha kecil bagi masyarakat Desa Batujajar Timur, serta BUMDesa Batujajar Timur. Pembangunan fisik di Desa Batujajar Timur belum terdapat perubahan secara merata dan menyeluruh di Desa Batujajar Timur, pembangunan fisik seperti jalan pemukiman, penerangan jalan, perbaikan sarana dan prasarana publik masih belum ada perubahan yang optimal dirasakan untuk beberapa bagian dusun atau RW (Rukun Warga) belum dilaksanakannya pembangunan, namun jalan utama Desa Batujajar Timur telah dilakukan pembangunan dan perbaikan. Pembangunan fisik maupun pembangunan non-fisik memiliki tujuan untuk menaikan tingkat hidup dan mutu hidup serta untuk kesejahteraan masyarakat desa.

Desa Batujajar Timur dalam pembangunan fisik dapat dikatakan belum efektif dengan melihat gejala-gejala fenomena pengelolaan alokasi dana desa di Desa Batujajar Timur. Efektivitas menurut (Handoko 1997) adalah kemampuan untuk memilih tujuan yang tepat untuk pencapaian tujuan yang telah ditetapkan. Selanjutnya dikemukakan oleh Ndraha (2005:163) menyatakan 
pengertian efektivitas "Efisiensi digunakan untuk mengukur proses, Efektivitas guna mengukur keberhasilan mencapai tujuan.” Lubis (1985:33) mengungkapkan bahwa efektivitas mengandung arti terjadinya suatu efek atau akibat seperti yang dikehendaki. Belum terlaksananya penerapan dimensi dalam pengelolaan alokasi dana desa yakni tepat, dan cepat. Tepat adalah apa yang dikehendaki tercapai, kena sasaran, memenuhi target apa yang dicita- citakan menjadi realistis (penyusunan program yang tepat).

\section{METODE PENELITIAN}

Penelitian ini bersifat fleksibel, sesuai dengan fakta empirik yang ada di lapangan selai itu penelitian ini berkembang sesuai dengan perkembangan subjek yang diteliti. Hal ini terjadi karena fenomena sosial yang terjadi di lapangan sangat dinamis. Metode deskriptif bahwa dengan menggunakan metode tersebut maka peneliti dapat menggambarkan dan menganlisa objek yang diteliti. Seperti yang di ungkapkan oleh Sugiyono (2012:29) mengatakan bahwa "Penelitian deskriptif bisa digunakan baik untuk menjawab pertanyaanpertanyaan penelitian (tidak berhipotesis) dan menguji hipotesis."

\section{PEMBAHASAN}

\section{Efektivitas Pengelolaan Alokasi Dana Desa Dalam Pembangunan Fisik Di Desa Batujajar Timur}

Alokasi Dana Desa diimplementasikan di Indonesia sejak tahun 2005 yang ditetapkan oleh Menteri Dalam Negeri Republik Indonesia dengan dasar Peraturan Pemerintah Nomor 72 tahun 2005 tentang Desa yang kini telah dipertegas dengan lahirnya Undang Undang Nomor 6 tahun 2014 tentang Desa, yang didalamnya diatur mengenai Alokasi Dana Desa yang merupakan kewajiaban Pemerintah Kabupaten untuk mengalokasikan dana melalui sumber transfer dari pemerintah pusat dan diteruskan kepada seluruh Desa tiap Kabupaten di Indonesia melalui Bendahara Desa di seluruh Indonesia. Alokasi Dana Desabersumber dari Anggarana Pendapatan dan Belanja Daerah (APBD) yang dialokasikan dengan tujuan pemerataan kemampuan keuangan setiap Desa untuk mendanai kebutuhan desa dalam rangka pelaksanakan pembangunan dan pemberdayaan masyarakat desa. Pemberian Alokasi Dana Desa ditetapkan 
melalui alur dari Pemerintah Kabupaten melalui Dinas Pembangunan dan Pemberdayaan Masyarakat Desa terkait yang penyalurannya melalui kas Desa. Alokasi Dana Desa digunakan dalam skala pembangunan Desa.

Alokasi Dana Desa yang didapat tiap Desa di tiap Daerah berbeda-beda dilihat dari letak geografis, jumlah penduduk miskin, jumlah penduduk tiap desa, dan juga potensi ekonomi, sehingga Alokasi Dana Desa berdasar pada azas merata dan adil. Pengelolaan Alokasi Dana Desa digunakan untuk pelaksanaan pembangunan serta pemberdayaan masyarakat desa yang dikelola secara mandiri oleh Pemerintah Desa yakni Kepala Desa yang dibantu Perangkat Desa yang diawasi oleh BPD.

Salah satu penggunaan Alokasi Dana Desa digunakan untuk Pembangunan karena pembangunan merupakan sebuah proses perubahan untuk mencapai tujuan mensejahterakan masyarakat melalui perkembangan dan pertumbuhan yang terencana. Pembangunan merupakan komponen yang penting karena dalam pelaksanaan pembangunan juga melibatkan masyarakat dan pemerintah agar berkesinambungan serta apa yang dibutuhkan masyarakat dalam pembangunan dapat dipenuhi oleh Pemerintah. Pembangunan baik fisik maupun non-fisik tidak hanya dilaksanakan dalam skala nasional saja melainkan dalam skala terendah tanpa mencederai konstitusi yakni Desa, karena pembangunan desa merupakan sebuah tolak ukur keberhasilan pembangunan nasional dengan mengimplementasikan apa yang tercantum didalam Undang-Undang Dasar 1945 Republik Indonesia sebagai landasan hukum yang didalamnya terdapat amanat untuk mensejahterakan masyarakatnya secara adil dan makmur. Dalam pelaksanaan pembangunan tidak hanya memberantas fenomena kemiskinan yang terjadi di sebagaian besar masyarakat desa, melainkan bagaimana memperbaiki sarana dan prasarana publik agar masyarakat nyaman.

Pengelolaan Alokasi Dana Desa dalam pembangunan fisik di Desa Batujajar Timur merupakan proses pengendalian, pengaturan, mengurus, menyelenggarakan anggaran alokasi dana desa guna keperluan pembangunan fisik yang dimulai dari tahap perencanaan sampai pada tahap evaluasi hal ini untuk kesejahteraan masyarakat berdasarkan aturan-aturan yang berlaku. Di Desa Batujajar Timur sendiri Alokasi Dana Desa mulai di implementasikan pada tahun 2010 dengan lahirnya Peraturan Daerah Kabupaten Bandung Barat Nomor 
15 Tahun 2009 tentang Alokasi Dana Desa. Dimana Desa Batujajar Timur mendapatkan sumber dana transfer Alokasi Dana Desa pada tahun 2010. Alokasi Dana Desa ini memiliki tujuan untuk pembangunan serta pemberdayaan masyarakat desa, karena Alokasi Dana Desa merupakan wujud pemenuhan hak desa untuk menyelenggarakan otomoninya sendiri. Desa Batujajar Timur perlu diberikan sumber danaseperti alokasi dana desa yang mencukupi sehingga pembangunan dapat terlaksana. Namun deminikan tidak hanya Alokasi Dana Desa saja yang diperlukan untuk melaksanakan pembangunan, sumber daya manusia dalam sebuah Pemerintahan Desa juga perlu diperhatikan, karena Pemerintah Desa yang akan mengelola Alokasi Dana Desa yang didapat secara mandiri tanpa campur tangan Pemerintah Kabupaten atau Pemerintah Pusat.

Pengelolaan Alokasi Dana Desa di Desa Batujajar Timur dibutuhkan tata kelola yang baik agar dana yang didapat tersebut tepat sasaran dan digunakan sesuai dengan peraturan perundang- undangan yang berlaku bagi pembangunan serta pemberdayaan masyarakat. Seiring berjalannya waktu Alokasi dana desa di Desa Batujajar Timur pada tahun anggaran 2017 dirasa lamban diterima oleh Kas Bendahara Desa Batujajar Timur melalui Dinas Pembangunan dan Pemberdayaan Masyarakat Desa, Alokasi Dana Desa tidak diterima pada tanggal 1 januari dan di laporkan pada 31 Desember selama satu periode. Serta Alokasi Dana Desa yang diterima oleh Pemerintah Desa Batujajar Timur dirasa tidak mengacu pada azas merata dan adil karena Alokasi Dana Desa yang didapat berbeda dengan Desa Cangkorah dengan jumlah penduduk yang sedikit, wilayah yang kecil dan memiliki potensi ekonomi yang tersedia. Alokasi Dana Desa yang dikelola secara mandiri dengan nominal angka yang besar untuk melaksanakan pembangunan terutama pembangunan fisik Desa Batujajar Timur belum mengalami perubahan yang siginifikan.

Alokasi Dana Desa digunakan dan dialokasikan dalam skala pembangunan serta pemberdayaan, dimana pembangunan merupkana suatu proses perubahan ke arah yang lebih baik dan maju, pembangunan mengacu pada pembangunan fisik dan pembangunan non-fisik dimana Pemerintah Desa melaksanakan pembangunan dengan mengacu pada pedoman pembangunan Desa dalam Peraturan Menteri Nomor 114 Tahun 2014 tentang Pedoman Pembangunan Desa. Sehingga pemerintah Desa Batujajar Timur harus mengacu pada 
peraturan perundang-undangan yang berlaku karena pembangunan memiliki tujuan untuk mensejahterakan masyarakat secara adil dan merata. Agar tujuan pembangunan terlaksana maka dalam hal pembangunan membutuhkan sumber dana yang perlu dikelola secara efektif agar tujuan dapat terlaksana sesuai dengan apa yang dicita- citakan.

Efektivitas merupakan sebuah kemampuan sebuah organisasi dalam mencapai tujuan dalam mengelola dapat dikatakan berhasil atau tidaknya organisasi mencapai tujuan yang diinginkan. Dalam mencapai tujuan yang berdaya guna efektivitas tersebut maka harus melalui beberapa prinsip yakni, Tepat, Cepat, Hemat, Selamat.

\section{a. Tepat}

Tepat sebagai dasar dari suatu yang akan diwujudkan atau dilaksanakna sesuai dengan apa yang direncanakan yang akan mempengaruhi hasil akhir dari tujuan yang ingin dicapai. Dalam suatu kegiatan atau aktivitas yaitu menetapkan cara yang tepat untuk mencapai tujuan organisasi. Tepat merupakan apa yang dikehendaki tercapai, tepat sasaran, memenuhi target, apa yang dicita-citakan menjadi realistis. Dalam pengelolaan alokasi dana desa tepat berarti memiliki tujuan yang akan di capai sesuai dengan target yang ingin dicapai oleh pemerintah Desa Batujajar Timur dalam waktu yang telah ditetapkan, dan tepat sasaran dalam pelaksanaannya. Dalam hal ini tepat berarti tercapainya tujuan dari pengelolaan alokasi dana desa yang dialokasikan untuk pembangunan fisik yang dilaksanakan di Desa Batujajar Timur.

\section{1) Ketepatan Waktu}

Ketepatan waktu sangat perlu diperhatikan dalam melaksanakan suatu kegiatan atau aktifitas baik yang dilaksanakan secara berkelompok maupun oleh individu yang mana suatu pekerjaan atau aktifitas perlu mengacu pada waktu yang telah ditentukan, karena jika suatu pekerjaan atau aktifitas tidak memiliki batasan waktu maka pekerjaan tersebut akan dilakukan secara lamban dan tidak memiliki tanggungjawab terhadap pekerjaan. Karena dalam pekerjaan atau kegiatan yang harus diperhatikan adalah waktu, karena akan berdampak pada hasil laporan pertanggungjawaban. Berdasarkan hasil wawancara peneliti dengan Sekretaris Desa Batujajar Beliau menjawab :

"Untuk pelakasanaan pembangunan fisik kami diberikan sumber 
dana transfer alokasi dana desa yang digunakan skala pembangunan desa, alokasi dana desa dicairkan per november 2017 dan harus dilaporkan sebagai pertanggungjawaban kepada Bupati Kabupaten Bandung Barat. Dan kami telah melaksanakan pembangunan fisik seperti jalan utama Desa Batujajar Timur dari Citunjung sampai dengan Haurngambang dengan jarak $1,8 \mathrm{Km}$, dan rambat beton yang kami buat dengan waktu yang kami tetapkan kepada pekerja yang membangun jalan utama dan rambat beton pada bulan januari 2018."

Demikian pula dengan yang diungkapkan oleh Bapak Wawan Suratwan selaku Kepala Urusan Kesejahteraan Masyarakat Desa Batujajar Timur beliau menjawab:

"Pembangunan fisik di Desa Batujajar Timur dilaksanakan dimulai sejak pertengahan desember 2017, dengan dilakukannya musrenbangdes yang dilaksanakan bersama dengan BPD Desa Batujajar Timur. Dan harus terselesaikan per Januari 2018 sebelum hasil laporan pertanggungjawaban dilaporkan kepada bupati pada bulan Maret 2018."

Begitu pula dengan hasil wawancara yang ditujukan untuk masyarakat Desa Batujajar Timur, Ibu R.Rosita. Beliau menjawab:

"Desa Batujajar Timur mulai dilaksanakan pada sekitar bulan Desember akhir dengan perbaikan dan pembangunan jalan utama Desa Batujajar Timur mulai dari Citunjung sampai Haurngambang. Sesuai dengan hasil musrenbangdes ditetapkan selesai pekerjaan pembangunan pada tanggal akhir januari tetapi melebih batas dari yang ditentukan. Lalu pembangunan tidak merata di Desa Batujajar Timur."

Pembangunan fisik di Desa Batujajar Timur memberikan jangka waktu kepada para pekerja baik dari pihak yang bekerjasama dengan Desa Batujajar Timur maupun masyarakat yang bergotong royong dalam partisipasi pembangunan jalan utama Desa Batujajar Timur, dengan pekerjaan yang dimulai pada pertengahan bulan Desember 2017 dengan waktu penyelesaian pembangunan jalan utama Desa Batujajar Timur pada bulan Januari 2018. Sebelum pada akhirnya Alokasi dana desa yang terdapat didalam APBDesa Batujajar Timur dilaporkan dan dipertanggungjawabkan kepada Bupati Kabupaten Bandung Barat. Namun 
yang menjadi permasalahan adalah keterlambatan pencairan alokasi dana desa yang tidak sesuai dengan Rencana Kerja yang telah dibuat oleh Pemerintah Desa yang ditetapkan menerima alokasi dana desa pada bulan januari tetapi tidak sesuai dengan apa yang telah ditetapkan oleh pemerintah.

Pembangunan fisik di Desa Batujajar Timur terutama dalam pembangunan dan perbaikan jalan belum semua dapat dilakukan secara optimal karena peneliti hanya menemukan jalan utama citunjung sampai Desa Batujajar Timur yang diperbaiki dengan aspal. Tetapi jalan Haurngambang belum diperbaiki maupun dibangun karena peneliti melihat jalan Haurngambang masih terdapat lubang-lubang dan jalan rusak yang seharusnya juga ikut diperbaiki dan dibangun oleh Pemerintah Desa Batujajar Timur karena jalan Haurngambang merupakan jalan utama Desa Batujajar Timur menuju ke Kota Cimahi dan Bandung yang selalu diakses oleh masyarakat Desa Batujajar Timur dan masyarakat Desa lainnya. Itu pula yang dirasakan oleh masyarakat Desa Batujajar Timur. Peneliti tidak menemukan adanya rambat beton yang dibangun di jalan utama Desa Batujajar Timur, pembangunan dan perbaikan jalan utama digunakan dengan menggunakan aspal.

\section{2) Adanya Target yang Ingin Dicapai}

Suatu pekerjaan dalam bidang apapun tentu memiliki target yang ingin dicapai yang akan menjadi sebuah tolak ukur dalam mencapai tujuan yang dicita- citakan. Target yang menjadi tolak ukur pelaksanaan dalam orgnanisasi adalah sebuah keberhasilan yang akan dicapai dengan memiliki tingkatakan tersendiri. Adanya target berarti dimulai dengan adanya program yang akan dilaksanakan untuk mencapai hasil akhir yang diinginkan. Karena target yang ingin dicapai harus tepat sasaran sesuai dengan yang direncanakan. Berdasarkan wawancara dengan Bapak Aang Suwandi selaku Sekretaris Desa Batujajar Timur, beliau menjawab:

"Target yang ingin dicapai oleh kami adalah pembangunan yang merata tentunya, tetapi kami juga perlu melihat kebutuhan apa yang dibutuhkan oleh masyarakat Desa Batujajar Timur dengan tidak bertindak diskriminasi, tentunya target yang ingin kami capai merata dan adil dalam pelaksanaan pembangunan Desa. Target yang ingin kami capai yaitu dengan membuat program-program 
atau rencana kerja yang kami tuangkan untuk dijalankan selama satu periode, kami juga membangun jalan, memperbaiki jalan dusun dengan melibatkan masyarakat desa Batujajar Timur dalam musrenbangdes. Sehingga target dalam pembangunan fisik ini adalah membuat masyarakat merasa nyaman jika pembangunan fisik telah terlaksana."

Hal diatas pun dipertegas oleh Bapak Wawan Suratwan selaku Kaur Kesejahteraan Masyarakat Desa Batujajar Timur, beliau menjawab:

"Alokasi dana desa yang kami dapatkan, dikelola untuk skala pembangunan fisik dan non fisik, kami melaksanakan musrenbangdes yang melibatkan tokoh masyarakat, ketua Rt dan ketua RW, perwakilan 3 orang tiap dusun. Dalam musrenbang yang dilaksanakan kami melihat dan mengetahui apa yang dibutuhkan oleh masyarakat Desa Batujajar Timur yang bersifat emergency untuk segera diperbaiki ataupun dibangun oleh Pemerintah Desa Batujajar Timur. Target yang ingin dicapai adalah pembangunan yang adil dan merata, tetapi adil belum merata dan merata belum tentu adil. Sehingga itu mengapa kami melibatkan masyarakat mulai dari perencanaan, pelaksanaan hingga evaluasi. Itupula yang menjadi keberhasilan kamu dalam pelaksanaan pembangunan, karena dana yang kami dapat dialokasikan dna digunakan sesuai dengan kebutuhan masyarakat, tepat sasaran, tepat waktu dan tepat administrasi."

Pengelolaan alokasi dana desa digunakan untuk pembangunan fisik berupa perbaikan dan pembangunan jalan sebagai target yang ingin dicapai dengan melibatkan masyarakat mulai dari tahap musrenbangdes sampai pelaksanaan pembangunan fisik yang akan dilaksanakan oleh pemerintah Desa Batujajar Timur dengan melibatkan masyarakat sebagai pekerja dalam perbaikan dan pembangunan jalan maupun pembangunan fisik di Desa Batujajar Timur. Namun kendalanya adalah bahwa pembangunan fisik dilakukan sesuai dengan kebutuhan masyarakat Desa Batujajar Timur. Alokasi dana desa yang diberikan oleh Pemerintah Kabupaten Bandung Barat kepada Desa Batujajar Timur digunakan dan dikelola sesuai dengan peraturan Bupati Kabupaten Bandung Barat dan

Peraturan Daerah Kabupaten Bandung Barat bahwa alokasi dana desa digunakan dalam skala pembangunan desa. Dalam pemberian alokasi dana desa yang diterima Desa Batujajar Timur tidak ada kendala pemberian dana yang dapat digunakan untuk melaksanakan rencana kerja untuk mencapai 
target yang ingin dicapai. Walau kendalanya bahwa masyarakat sekitar Desa Batujajar Timur merasa bahwa pembangunan fisik belum merata di beberapa Dusun. Kenyataannya pembangunan fisik memang belum optimal dan merata di Desa Batujajar Timur.

\section{b. Cepat}

Suatu pekerjaan yang akan dilaksanakan sebelum waktu yang telah ditentukan, namun dalam melaksanakan pekerjaan perlu berhati-hati saat melaksanakannya. Dan perlu dengan cermat memilah dan memilih pekerjaan yang sesuai dengan kemampuan. Dalam hal ini pembangunan fisik di Desa Batujajar Timur perlu memanfaatkan waktu dalam melaksanaan tugas yang diberikan. Dan perlu bertanggungjawab terhadap tugas yang telah diberikan sehingga pekerjaan dapat terlaksana. Dalam pengelolaan alokasi dana desa yang digunakan untuk pembangunan di Desa sebagai pekerjaan yang dilakukan oleh Pemerintah Desa juga perlu adanya pengawasan dari masyarakat maupun BPD Desa.

\section{1) Bertanggungjawab Terhadap Tugas}

Suatu pekerjaan atau tugas tentu memiliki sebuah pertanggungjawaban yang harus dilaksanakan dan dilaporkan kepada yang memberik tugas dan kewenangan. Sehingga suatu pekerjaan yang dilaksanakan perlu adanya pertanggungjawaban sebagai sebuah kinerja yang akan dinilai. Seperti hasil wawancara yang dilakukan dengan Bapak Aang selaku Sekretaris Desa, beliau menjawab:

"Alokasi dana desa yang diberikan melalui kas Desa Batujajar Timur kami musyawarahkan dengan tim pelaksana untuk memenuhi kebutuhan apa yang dibutuhkan oleh masyarakat Desa Batujajar Timur." 
Adapun yang menjadi rincian kebutuhan sebagai berikut:

Tabel 2

Kebutuhan Tim Pelaksana

\begin{tabular}{|c|l|}
\hline No & \multicolumn{1}{|c|}{ Tugas Tim Pelaksana Desa } \\
\hline 1 & $\begin{array}{l}\text { Menyusun perencanaan penggunaan ADD yang } \\
\text { melibatkan BPD, LPMD, dan lembaga kemasyarakatan } \\
\text { guna membahas masukan dan usulan yang dituangkan } \\
\text { dalam rancangan } \\
\text { APBDesa Batujajar Timur }\end{array}$ \\
\hline 2 & $\begin{array}{l}\text { Memberi masukan dalam penyusunan rancangan Perdes } \\
\text { tentang APBDesa untuk mendapat persetujuan dari BPD, } \\
\text { dan disosialisasikan kepada masyarakat }\end{array}$ \\
\hline 3 & $\begin{array}{l}\text { Menyusun jadwal rencana pencairan dana dan melakukan } \\
\text { kegiatan } \\
\text { pertanggungjawaban }\end{array}$ \\
\hline 4 & $\begin{array}{l}\text { Melaporkan perkembangan pelaksanaan kegiatan ADD } \\
\text { secara periodik tiap bulan kepada tim pendamping tingkat } \\
\text { Kecamatan } \\
\text { Bertanggungjawab terhadap pelaksanaan seluruh kegiatan } \\
\text { yang dibiayai dari ADD }\end{array}$ \\
\hline 5
\end{tabular}

\section{Sumber: Sekretaris Desa Batujajar Timur, diolah oleh Peneliti 2018}

Alokasi dana desa yang diterima oleh Pemerintah Desa Batujajar Timur lalu mengadakan musyawarah untuk melaksanakan kegiatan dan merealisasikan sesuai dengan RPD yang telah disahkan. Dan bertanggungjawab secara keseluruhan terhadap penggunaan ADD ditingkat Desa. Walaupun Alokasi dana desa yang kami terima memiliki sedikit hambatan yang tidak diberikan pada bulan januari dan dilaporkan pada bulan Desember. Tetapi kami tetap melaksanakan laporan pertanggungjawaban kepada Pemerintah Kabupaten.

Pelaksanaan sosialisasi alokasi dana desa yang telah diterima oleh 
Pemerintah Batujajar Timur telah melibatkan masyarakat dalam musrenbang, dengan partispasi masyarakat yang hadir dalam kegiatan musrenbang sebanyak 25 orang. Tetapi peneliti tidak menemukan adanya publikasi besaran ADD yang disimpan di ruang publik sesuai dengan prinsip good governance yakni transparansi dimana alokasi dana desa yang terdapat didalam APBDesa perlu disimpan di ruang publik atau yang dapat diakses oleh masyarakat umum. Adanya sosialiasi yang melibatkan masyarakat Desa Batujajar Timur sebagai bentuk salah satu pertanggungjawaban pemerintah Desa Batujajar Timur. Sehingga belum efektifnya partisipasi masyarakat Desa Batujajar Timur dalam musrenbangdes dan sosialisasi mengenai alokasi dana desa yang akan digunakan untuk kebutuhan masyarakat Desa Batujajar Timur. Jika melihat dari data demografis Batujajar Timur, jumlah penduduk sebanyak 15.000 jiwa lebih dalam pelaksanaan musrenbangdes sebanyak 25 orang dapat dikatakan tidak adanya partisipasi dan kepedulian masyarakat akan barang publik.

\section{2) Memanfaatkan Waktu Dalam Kegiatan}

Memanfaatkan waktu dalam melaksanakan kegiatan artinya bahwa dalam mengerjakan segala sesuatu pekerjaan harus tepat waktu dalam pelaksanaan agar pertanggungjawabanya sesuai dengan waktu yang telah ditetapkan. Dalam pengelolaan alokasi dana desa yang diterima perlu dikelola demi kepentingan dan kesejahteraan masyarakat sesuai dengan waktu yang didtetapkan per setahun sekali atau tiap satu periode mulai dari penerimaan alokasi dana desa hingga pelaksanaan selama satu periode sampai pada evaluasi yang di laporkan setiap akhir tahun. Berdasarkan hasil wawancara peneliti dengan Bapak Aang Suwandi pada tanggal 2 Agustus 2018 pukul 12.16 (pertanyaan nomor 4 pada pedoman wawancara untk Sekretaris Desa) selaku Sekretaris Desa Batujajar Timur, terkait dengan waktu pelaksanaan. Beliau menjawab :

"Kami mendapatkan alokasi dana desa tahun anggaran 2017 dan dicairkan pada bulan November 2017, dan harus dilaporkan pada bulan Maret 2018, sehingga kami perlu dengan cepat mengadakan musyawarah dengan masyarakat Desa Batujajar Timur, apa yang dibutuhkan oleh masyarakat Desa Batujajar Timur, jika melihat itu tidak sesuai dengan apa yang telah di beritahukan oleh pemerintah Kabupaten bahwa Alokasi Dana Desa di dapat pada tanggal 31 
Januari dan di laporkan kembali kepada Pemerintah Kabupaten per tanggal 1 Desember. Sehingga dengan waktu yang singkat kami tetap mengelola alokasi dana desa untuk pemberdayaan dan pembangunan. dan pembangunan fisik yang dilakukan dalam tahap perbaikan sarana dan prasarana seperti posyandu, jalan, dan lainnya. Pada bulan Maret 2018 kami melaporkan hasil kegiatan dan pertanggungjawaban kepada Bupat Kabupaten Bandung Barat.Sebagai hasil selama satu tahun periode kerja Desa Batujajar Timur."

Pemberian Alokasi Dana Desa Tahun anggaran 2017 belum tepat waktu dari Pemerintah Kabupaten yang diberikan kepada Pemerintah Desa Batujajar Timur, dengan ketetapan yang telah di tetapkan, seharusnya Alokasi Dana Desa diberikan pertanggal 1 Januari dan di pertanggungjawabkan per tanggal 31 Desember. Dalam waktu kurang dari 4 bulan Pemerintah Desa Batujajar Timur harus segera melaporkan penggunaan dana yang didapat dengan biaya belanja yang dikeluarkan untuk pelaksanaan pembangunan serta pemberdayaan masyarakat Desa Batujajar Timur.

\section{c. Hemat}

Hemat memiliki arti tidak boros, atau dengan biaya yang sekecil-kecilnya memperoleh apa yang diharapkan tanpa adanya pemborosan dalam melakukan kegiatan apapun. Dalam Pemerintahan tentu Hemat merupakan hal yang perlu diperhatikan terutama dalam melaksanakan kegiatan yang berkaitan dan membutuhkan dana. Terutama dalam pengelolaan alokasi dana desa perlu menerapkan prinsip hemat agar tujuan yang ingin dicapai sesuai dengan apa yang telah direncanakan.

\section{1) Tidak terjadinya Pemborosan}

Sumber dana merupakan suatu hal yang penting untuk melaksanakan kegiatan di dalam sebuah pemerintahan, dengan adanya sumber dana baik yang berasal dari Daerah maupun Pemerintah Pusat guna melaksanakan urusan pemerintahan yang akan dijalankan sesuai dengan fungsi pemerintah. Sumber dana yang didapat oleh Pemerintah Desa salah satunya adalah merupakan program pemerintah Pusat yang menjadi kewajiban Pemerintah Kabupaten untuk memberikan Alokasi Dana Desa kepada Desa 
untuk menjalankan urusan Pemerintahannya tanpa adanya campur tangan dari pihak manapun dan akan dipertanggungjawabkan kepada Bupati. Alokasi Dana Desa yang didapat oleh Desa Batujajar Timur dilakukan dan dirumuskan oleh Kepala Desa yang dibantu oleh Perangkat Desa untuk melaksanakan kegiatan pemerintahan.

\section{d. Selamat}

Pengelolaan Alokasi Dana Desa merupakan bagian dari Pemerintah Desa agar Desa mampu menjalankan urusan pemerintahannya secara mandiri, tanpa ada interpresi dari pihak manapun, Pemerintah Desa sebagai pihak yang memiliki wewenangnya untuk membelanjakan apa yang menjadi kebutuhan untuk pelaksanaan fungsi pemerintah dari dana yang didapat baik dari Pemerintah pusat maupun Pemerintah Daerah. Agar pengelolaan Alokasi Dana Desa dapat dikatakan berhasil perlu mengacu pada sumber daya manusia yang memadai yang dapat mengelola sumber dana yang dimiliki guna mencapai tujuan tidak hanya untuk orgnanisasi Pemerintah Desa saja melainkan kepada masyarakat Desa.

Selamat memiliki arti yakni segala sesuatu sampai pada tujuan yang dimaksud tanpa mengalami hambatan-hambatan.Dimana jika suatu organisasi mendapatkan hambatan maka organisasi tersebut perlu mencari solusi yang tepat agar tujuannya dapat terlaksana seperti yang diinginkan.Dalam menjalankan fungsi pemerintah, salah satunya dalam hal pembangunan fisik yang menjadi fokusn utama dalam menjalankan fungsi pemerintah yang perlu diperhatikan karena berkaitan dengan dampak secara langsung yang dirasakan oleh masyarakat.

Untuk menjabarkan Selamat dalam pengelolaan Alokasi Dana Desa, terdapat indikator yang menjadi tolak ukur yakni sebagai berikut:

Perencanaan yang matang merupakan tahapan awal bagi pemerintah yang perlu diperhatikan, tidak hanya dilakukan oleh pemerintah pusat maupun pemerintah Daerah tetapi perencaan perlu di formulasikan atau dirancang oleh Pemerintah Desa dalam menjalankan urusan pemerintahannya dan melaksanakan fungsi pemerintah. Perencanaan yang matang dilakukan oleh Pemerintah Desa dengan membuat visi misi yang jelas terlebih dahulu, yang akan menjadi acuan Pemerintah Desa menjalankan pemerintahannya, visi misi yang jelas dibuat oleh 
Kepala Desa selaku kepala pemerintahan Desa yang dibantu oleh perangkat desa. Pemerintahan Desa yang memiliki visi dan misi yang jelas terhadap masa depan tujuan yang hendak dicapai bersifat mendasar namun memiliki dampak untuk organisasi pemerintahan desa maupun masyarakat desa itu sendiri.

\section{1) Tidak terjadinya pemborosan}

Dalam melaksanakan pengelolaan alokasi dana desa tentu pemerintah desa perlu merumuskan dan membuat perencanaan yang matang agar pembangunan baik fisik maupun non-fisik dapat berjalan seperti apa yang diinginkan sesuai dengan visi dan misi yang telah dibuat oleh Pemerintah Desa, terutama dalam pelaksanaan pembangunan dengan mengacu pada Rencana Pembangunan Jangka Menengah Desa (RPJMDes) yang dibuat sesuai dengan masa jabatan Kepala Pemerintah Desa selama menjabat di Desa tersebut. Tahap perencanaan Pengelolaan Alokasi Dana Desa di Desa Batujajar Timur Kecamatan Batujajar, telah sesuai dengan ketentuan yang berlaku dimana diawali dengan pembentukan tim pelaksana dan proses perencanaan dilakukan dengan model partisipatif masyarakat Desa dalam kegiatan musrembang Desa. Karena perencanaan yang matang tidak hanya mengacu pada visi dan misi yang telah dibuat tetapi perumusan dalam musrenbang yang diadakan menjadi sebuah acuan agar pemerintah Desa dapat melaksanakan apa yang dibutuhkan oleh masyarakat desa salah satunya dalam pembangunan fisik.

Berdasarkan hasil wawancara Peneliti dengan Bapak Aang Suwandi terkait dengan perencanaan yang matang dalam pengelolaan Alokasi Dana Desa Desa Batujajar Timur untuk mencapai tujuan dalam mensejahterakan masyarakat Desa Batujajar Timur. Beliau menjawab :

"Perencanaan yang matang dimulai dengan membuat visi dan misi yang dibuat oleh Kepala Desa Batujajar Timur yang akan menjadi acuan bagi kami selaku perangkat desa untuk mengimplementasikan visi dan misi yang telah kami buat sedemikian rupa, yang mana visi dan misi ini dibuat sampai pada tahun 2019 yang dimulai pada tahun 2013. Karena dalam menjalankan fungsi pemerintah dan urusan pemerintahan kami memiliki tugas dan fungsinya masing-masing sehingga tidak adanya tumpang tindih yang terjadi di dalam pemerintahan.Masyarakat dapat dikatakan sejahtera jika pembangunan telah dilaksanakan 
secara merata sesuai dengan amanat Undang-Undang Dasar tahun 1945.Dengan mengacu pada visi dan misi yang telah dibuat."

Pemerintah Desa Batujajar Timur telah membuat perencanaan yang mengikut sertakan masyarakat sekitar, untuk mengetahui apa yang dibutuhkan oleh masyarakat Desa Batujajar Timur terutama dalam pembangunan fisik Desa Batujajar Timur. Pemerintah Desa juga telah membuat visi misi yang jelas untuk mengimplementasikan kepada masyarakat agar masyarakat sejahtera. Visi dan misi tersebut memiliki sasaran strategis dan dan program kegiatan yang akan di implementasikan untuk mencapai tujuan yang diinginkan salah satu program yang akan dilaksanakan adalah pembangunan baik fisik maupun non-fisik demi tecapainya tujuan untuk mensejahterakan masyarakat Desa Batujajar Timur. Karena perencanaan yang matang tidak hanya visi dan misi yang jelas yang perlu di perhatikan tetapi keterlibatan seluruh elemen masyarakat mulai dari tokoh masyarakat hingga masyarakat Desa, dengan adanya musrenbang Desa yang melibatkan keiikutsertaan masyarakat Desa sehingga pemerintah Desa dapat mengetahui apa yang menjadi kebutuhan masyarakat Desa dalam hal pembangunan. Sehingga Alokasi Dana Desa yang dimiliki dilakukan dengan perencanaan yang matang guna menjalankan salah satu fungsi pemerintah yang menjadi fokus pada pembangunan di Desa terutama dalam hal pembangunan fisik di Desa.

Sejalan dengan pertanyaan kepada masyarakat Desa Batujajar Timur Ibu R. Rosita selaku Ketua Tim Penggerak PKK RW, terkait dengan bagaimana keterkaitan masyarakat Desa Batujajar dalam perencanaan yang dibuat oleh Pemerintah Desa. Beliau menjawab:

"Pemerintah Desa selalu mengikutsertakan kami masyarakatnya dalam musrenbang dimana ada perwakilan 3 orang dari tiap rukun warga, tokoh masyarakat, serta masyarakat Desa Batujajar Timur, pemerintah mempublikasikan perencanaan yang akan dibuat untuk pembangunan, dan mempublikasikan sumber dana yang didapat dan diterima oleh Pemerintah Desa Batujajar Timur. Pemerintah Desa akan memberitahukan kepada masyarakatnya berapa dana yang didapat melalui sumber apa saja dana di terima dan apa yang menjadi kebutuhan masyarakat yang perlu dipenuhi oleh Pemerintah Desa Batujajar Timur." 
Keterlibatan masyarakat Desa Batujajar Timur merupakan unsur dalam sebuah perencanaan dalam pengelolaan alokasi dana desa untuk pembangunan fisik Desa Batujajar Timur. Karena dengan Pemerintah Desa perlu melibatkan elemen masyarakat dan mempublikasikan kepada masyarakat agar menimbulkan sebuah kepercayaan kepada Pemerintah Desa dalam mengelola sumber dana yang didapat yang nominalnya tidak sedikit, dan masyarakat perlu berpartisipasi mulai dari tahap perencanaan hingga tahap evaluasi. Masyarakat Desa Batujajar Timur tidak selalu dilibatkan dalam proses pelaksanaan pemerintahan, tetapi bukti dilapangan mengenai publikasi secara transparan kepada masyarakat mengenai keuangan yang diterima berupa APBDesa tidak di publikasikan di tempat publik, jika mengacu pada ketetapan yang dibuat oleh Menteri Dalam Negeri bahwa Pemerintah perlu mempublikasikan pendapatan dan belanja Daerah/Desa diruang publik yang dapat diakses oleh masyarakat dan dilihat secara langsung. Namun peneliti tidak menemukan publikasi diruang publik. Jika melihat dalam perencanaan yang matang dalam pengelolaan alokasi dana desa maka didalamnya terdapat visi misi yang jelas, partisipasi masyarakat Desa melalui musrenbang Desa. sehingga perencanaan yang matang dapat menghasilkan tujuan yang diinginkan melalui unsur tersebut, jika unsur yang telah dissebutkan tidak terdapat maka perencanaan yang matang belum dapat mencapai apa yang ingin dicapai.

Sejalan dengan hasil wawancara dengan Bapak Aang Sekretaris Desa Batujajar Timur Berkaitan dengan perencanaan Pemerintah Desa dalam mengelola sumber dana Alokasi Dana Desa guna pembangunan di Desa. Beliau menjawab sebagai berikut:

"Selaku Pemerintah Desa kami mengelola secara mandiri dana yang didapat baik dari Pemerintah Kabupaten atau Pusat untuk selanjutnya dana yang didapat dikelola dan digunakan untuk menjalankan fungsi pemerintah desa, terutama dana yang bersumber melalui transfer yang menjadi kewajiban Pemerintah Kabupaten yang diberikan kepada Kas Desa, perencanaan yang kami buat guna pembangunan di Desa Batujajar ini tertuang dalam APBDesa yang mana pendapatan yang diterima berasal darimana dan di belanjakan untuk apa, karena akan ada laporan pertanggungjawaban yang harus diberikan kepada Pemerintah Kabupaten. Sehingga perencanaan yang matang kami buat dengan seksama sesuai dengan kebutuhan apa saja yang diperlukan untuk 
urusan pemerintahan serta apa yang dibutuhkan oleh masyarakat agar masyarakatnya sejahtera, salah satunya dengan pembangunan yang dilaksanakan oleh pemerintah Desa Batujajar Timur."

Perencanaan yang matang merupakan hal terpenting sebelum melaksanakan pembangunan maupun urusan pemerintahan lainnya, denganperencanaan yang matang dalam pengelolaan sumber dana yang didapat melalui pemerintah Kabupaten karena dikelola secara mandiri maka perencanaan yang matang yang mengacu pada visi dan misi yang jelas. Dapat dikatakan bahwa indikator dalam "selamat" terpenuhi karena memang benar adanya perencanaan yang matang tidak hanya mengacu pada visi dan misi yang jelas di Desa Batujajar Timur, tetapi bagaimana pengelolaan alokasi dana desa yang diterima oleh pemerintah Desa Batujajar Timur dapat digunakan guna kepentingan kesejahteraan masyarakat Desa Batujajar Timur.

\section{2) Tersedianya sumber daya yang memadai}

Sumber daya sangat dibutuhkan dalam pelaksanaan pembangunan yang bersumber dari sumber dana yang didapat yakni alokasi dana desa, yang digunakan dalam skala pembangunan. Sumberdaya manusia terutama sangat dibutuhkan untuk mengelola barang publik untuk memenuhi kebutuhan masyarakat. Dalam hal ini sumber daya manusia selaku aparatur desa harus berkompeten terhadap keuangan yang didapat dengan menerapkan prinsip hemat, terarah dan terkendali. Sumberdaya lain seperti sarana dan prasarana yang menujang Pemerintah Desa Batujajar Timur. Berdasarkan data dibawah ini :

Tabel 3

Sumber Daya Manusia

\begin{tabular}{|c|l|l|l|}
\hline No & \multicolumn{1}{|c|}{ Nama } & \multicolumn{1}{|c|}{ Jabatan } & Pendidikan \\
\hline 1 & Mochtar & Kepala Desa & SMA \\
\hline 2 & Aang Suwandi & Sekretaris Desa & SMA \\
\hline 3 & Ayi Suriatna & Kaur & SMA \\
& & Pemerintahan & \\
\hline 4 & Sri Rahayu & Kaur Keuangan & SMA \\
\hline 5 & Indun Ratnasari & Kaur Umum & SMA \\
\hline
\end{tabular}




\begin{tabular}{|l|l|l|l|}
\hline 6 & Ucu & Kaur Pelayanan & SMA \\
\hline 7 & Wawan Sutarwan & Kaur Kesra & SMA \\
\hline
\end{tabular}

Sumber daya manusia diatas belum dapat dikatakan berkomenten karena jika melihat dari pendidikan terakhir maka aparatur Desa dalam mengelola barang publik yang dikelola secara mandiri dapat diragukan oleh masyarakat. Sarana dan prasarana menjadi hal yang sangat dibutuhkan guna menunjang kegiatan yang akan dilakukan oleh Pemerintah Desa, baik sarana dan prasarana publik maupun sarana dan prasarana yang terdapat didalam Pemerintahan Desa. karena sarana dan prasarana adalah alat untuk mencapai tujuan yang ingin dicapai. Sarana dan prasarana Pemerintahan Desa seperti ruang kerja, ruang tunggu, dan fasilitas seperti komputer merupakan bagian yang penting guna memperlancar tujuan dari Pemerintah Desa Batujajar Timur sebagai alat pendukung. Sedangkan sarana dan prasarana publik seperti jalan, sarana olahraga.

Peneliti mewawancarai Bapak Aang Suwardi berkaitan dengan sarana dan prasarana. Beliau menjawab:

"Sarana dan prasarana di kantor Desa Batujajar Timur telah menunjang kami untuk melakukan urusan pemerintahan, dengan adanya komputer untuk mempermudah masyarakat Desa Batujajar Timur mengakses tentang Desa Batujajar Timur, seperti profil Desa, Demografis. Sarana dan prasarana publik juga telah diperbaikinya sarana seperti posyandu dan sarana olahraga Gor Batujajar Timur. Dengan Alokasi Dana Desa yang kami dapat kami kelola untuk perbaikan dan pembangunan sarana dan prasarana Desa Batujajar Timur."

Sarana dan prasarana menjadi bagian yang penting dalam menunjang kegiatan pemerintahan Desa Batujajar Timur.Baik sarana dan prasarana Pemerintahan sebagai alat untuk melaksanakan tugas untuk mencapai tujuan yang diinginkan.Serta sarana dan prasarana publik yang diperbaiki maupun dibangun guna mencapai tujuan dari Pemerintah Desa untuk mensejahterakan masyarakat Desa Batujajar Timur. Sejalan dengan hasil wawancara dari Bapak Wawan Suratwan Beliau menjawab :

"Sarana dan prasarana publik terutama dalam hal pembangunan, kami mengutamakan lahan yang akan digunakan untuk pembangunan dan perbaikan sarana dan prasarana. Dan kami merasa hampir semua sudah terbangun dari pembangunan fisik 
seperti jalan gang, jalan umum atau jalan utama Desa Batujajar Timur.Dengan dilakukannya pembangunan jalan utama dengan aspal, jalan gang dengan pamimblok sehingga pembangunan infrastruktur sesuai dengan kebutuhan masyarakat.Perbaikan posyandu di beberapa rukun warga juga telah diperbaiki sesuai dengan kebutuhan masyarakat Desa Batujajar Timur. Ada pula kami berhasil membuat pengadaan air bersih di 3 (tiga) Rukun warga yakni RW 4,5, dan 6, yang dikelola oleh BP Badan Desa.”

Pembangunan dan perbaikan sarana olahraga belum dilaksanakan sesuai dengan fakta yang peneliti temukan di lapangan. Dan jika melihat pada pembangunan jalan Desa Batujajar Timur telah dilaksanakan pada jalan utama Desa Batujajar Timur dan beberapa jalan gang Rukun Warga atau dusun yang ada di Desa Batujajar Timur yang peneliti temui faktnya secara langsung. Dimensi Hemat dari kedua indikator yang ada dapat dikatakan terlaksana, walaupun pada kenyataanya bahwa pemberian alokasi dana desa didapatkan tidak sesuai dengan realisasi dan waktu yang telah ditetapkan, namun pemerintah Desa Batujajar Timur telah melaksankan dan menjalankan pembangunan melaui dana yang didapat dari Pemerintah Daerah.

\section{KESIMPULAN}

Berdasarkan hasil penelitian dan pembahasan sebagaimana yang telah diuraikan sebelumnya mengenai Efektivitas Pengelolaan Alokasi Dana Desa Dalam Pembangunan Fisik Desa Batujajar Timur. Apabila dilihat dari dimensi dan teori dari Drucker maka peneliti mengambil kesimpulan sebagai berikut :

1. Dari segi Tepat dari kedua indikator belum optimal karena keterlambatan pencairan dana yang diterima oleh Pemerintah Desa tidak sesuai dengan realitas.

2. Dari segi Cepat belum efektifnya pengelolaan alokasi dana desa Bertanggungjawab Terhadap Tugas, indikator ini dapat dikatakan telah optimal karena, namun partisipasi masyarakat yang kurag. Pemerintah Desa Batujajar Timur telah melaksanakan laporan pertanggungjawaban Alokasi Dana Desa kepada Bupati Kabupaten Bandung Barat melalui Dinas Pembangunan dan Pemberdayaan 
Masyarakat Desa dan laporan pertanggungjawaban menjadi bagian akhir dari tahap evaluasi.

3. Hemat, dari dua indikator yang tersedia dapat dikatakan bahwa pengelolaan alokasi dana desa memperhatikan prinsip hemat untuk mencapai tujuan yang diinginkan. Walaupun alokasi dana desa yang didapat Desa Batujajar Timur tidak tepat waktu dalam pencairan tersebut, tetapi pemerintah Desa Batujajar Timur menggunakan dana dari gotong royong swadaya masyarakat. Sehingga tujuan dapat terlaksana dan tidak terjadinya pemborosan.

4. Selamat

a. Perencanaan yang matang, dikatakan sudah jelas karena perencanaan yang matang untuk melaksanakan pembangunan, perencanaan yang matang dengan merumuskan apa yang akan dilakukan untuk mencapai tujuan dengan melibatkan masyarakat dalam proses perencanaan melalui musrenbang Desa.

b. Sumberdaya yang memadai, belum dapat dikatakan berkompeten aparatur Desa jika melihat pada pendidikan terakhir kepala desa beserta perangkat desa.

\section{DAFTAR PUSTAKA}

\section{Buku-Buku:}

Adisasmita, Rahardjo. 2011. Pengelolaan Pendapatan Dan Anggaran Daerah. Yogyakarta: Graha Ilmu.

2013. Pembangunan Perdesaan. Yogyakarta: Graha Ilmu

Dwipayana, Aridan Suntoro Eko. 2003. Membangun Good Governance Di Desa. Yogyakarta: Institute Of Research and Empowerment.

Effendi, Bachtiar. 2002. Pembangunan Daerah Otonom Berkeadilan. Yogyakarta: Uhaindodan dan Offset.

Fakih, Mansour. 2001. Sesat Pikir Teori Pembangunan Dan Globalisasi. Yogyakarta: Pustaka Pelajar.

Herlianto, Didit. 2017. Manajemen Keuangan Desa: Berbasis Pada Peraturan Menteri Dalam Negeri Republik Indonesia Nomor 113 Tahun 2014 Tentang Pengelolaan Keuangan Desa. Yogyakarta: Gosyen Publishing. 
Lubis, Ibrahim. 1985. Pengendalian dan Pengawasan Proyek dalam Manajemen. Jakarta: Ghalia Indonesia

Makmur. 2011. Efektivitas Kebijakan Kelembagaan Pengawasan. Bandung: PT Refika Aditama.

Moleong, Lexy J. 2012. Metode Penelitian Kualitatif Edisi Revisi. Bandung: PT Remaja Rosdakarya.

Ndraha, Taliziduhu. 2005. Teori Budaya Organisasi. Bandung: Rineka Cipta.

Nurcholis, Hanif. 2011. Pertumbuhan Dan Penyelenggaraan Pemerintahan Desa. Jakarta: Erlangga.

Rosidin, Utang. 2015. Otonomi Daerah Dan Desentralisasi: Dilengkapi UU Nomor 11 Tahun 2015, UU Nomor 2 Tahun 2015, Serta UU Nomor 8 dan 9 Tahun 2015. Bandung: Pustaka Setia.

Sedarmayanti. 2009. Sumber Daya Manusia Dan Produktivitas Kerja. Bandung: CV Mandar Maju.

Sugiyono. 2016. Metode Penelitian Kualitatif, Kuantitatif Dan R\&D. Bandung: Alfabeta.

Widjaja, AW. 1996. Pemerintahan Desa Dan Administrasi Desa : Menurut Undang Undang Nomor 5 Tahun 1979 (Sebuah Tinjauan). Jakarta: PT RajaGrafindo Persada

Yuwono, Teguh. 2001. Manajemen Otonomi Daerah : Membangun Daerah Berdasarkan Paradigma Baru. Semarang: Clyapps Dipenogoro University.

\section{Jurnal:}

Agustina, Amelyana. Efektivitas Dana Pembangunan Fisik Desa Puncangro Kecamatan Gudo Kabupaten Jombang. V(2). No 4 : 735- 739. (Diakses pada 15 Desember 2017)

\section{Dokumen-Dokumen:}

Undang Undang Nomor 23 Tahun 2014 Tentang Pemerintahan Daerah

Undang Undang Nomor 6 tahun 2014 Tentang Desa

Peraturan Daerah Kabupaten Bandung Barat Nomor 12 Tahun 2009 Tentang Alokasi Dana Desa

Peraturan Menteri Dalam Negeri Nomor 113 Tahun 2014 Tentang Pengelolaan Alokasi Dana Desa

Peraturan Menteri Dalam Negeri Nomor 114 Tahun 2014 Tentang Pedoman Pembangunan Desa

Peraturan Daerah Kabupaten Bandung Barat Nomor 15 Tahun 2009 Tentang Alokasi Dana Desa 
Peraturan Bupati Kabupaten Bandung Barat Nomor 12 Tahun 2015 Tentang Tatacara Pengalokasian Alokasi Dana Desa

Peraturan Desa Batujajar Timur Nomor 2 Tahun 2017 Tentang APBDesa Batujajar Timur 